\title{
Ractopamine in diets for finishing gilts ${ }^{1}$
}

\section{Pedro Henrique Watanabe ${ }^{2}$, Maria Cristina Thomaz ${ }^{2}$, Leonardo Augusto Fonseca Pascoal'2, Urbano dos Santos Ruiz² ${ }^{2}$ Everton Daniel$^{2}$, José Cristani ${ }^{3}$}

\author{
${ }^{1}$ FAPESP. \\ 2 Universidade Estadual Paulista - Faculdade de Ciências Agrárias e Veterinárias - Campus de Jaboticabal \\ 3 Universidade Estadual de Santa Catarina - Centro de Ciências Agroveterinárias.
}

\begin{abstract}
An experiment was carried out using 468 gilts, with an initial weight of $84.77 \pm 7.20 \mathrm{~kg}$ and allotted into 36 pens to evaluate the effect of the addition of ractopamine in the diets on performance, characteristics and yields of carcass comercial cuts, composition and retail cuts of ham. It was used a randomized block design with four levels of ractopamine $(0,5,10$ and $15 \mathrm{mg} / \mathrm{kg}$ of diet) and nine replicates with 13 animals per experimental unit. The initial body weight of the animals was the criterion used to form the blocks. It was not observed any effects of levels of ractopamine on daily weight gain of the animals. Daily feed intake presented a linear reduction when the level of dietary ractopamine was increased. Feed conversion of the animals was linearly improved with the inclusion of ractopamine in the diet. Significant differences were verified at fat and meat proportions on the carcass and wholesale cuts. There was a decreasing linear effect caused by ractopamine on the quantity and depth of fat and a linear increasing effect on lean percentage, on ham meat and on the weights of semimembranosus and gluteus medius. Diets for finishing gilts should contain $15 \mathrm{mg} / \mathrm{kg}$ of ractopamine per $\mathrm{kg}$.
\end{abstract}

Key Words: $\beta$ adrenergic agonist, carcass traits, nutrient partitioning agent, performance

\section{Ractopamina em dietas para fêmeas suínas na fase de terminação}

\begin{abstract}
RESUMO - Foi realizado um experimento utilizando-se 468 fêmeas, com peso inicial de 84,77 \pm 7,20 kg, alojadas em 36 baias, para avaliar os efeitos da adição de ractopamina nas dietas sobre o desempenho, as características e os rendimentos de cortes comerciais da carcaça, a composição e os cortes cárneos do pernil. O desenho experimental usado foi o de blocos ao acaso com quatro níveis de ractopamina (0, 5, 10 e $15 \mathrm{mg} / \mathrm{kg}$ de dieta) e nove repetições com 13 animais por unidade experimental. O critério para formação dos blocos foi o peso inicial dos animais. Não foram observados efeitos dos níveis de ractopamina sobre o ganho de peso diário dos animais. O consumo diário de ração apresentou redução linear com o aumento do nível de ractopamina nas dietas. A conversão alimentar dos animais melhorou de forma linear com a inclusão de ractopamina na dieta dos animais. Verificaram-se também diferenças significativas na proporção de gordura e carne na carcaça e nos cortes cárneos. Houve efeito linear decrescente da ractopamina sobre a quantidade e profundidade de gordura e efeito linear crescente sobre a porcentagem de carne magra, de carne no pernil e sobre os pesos de semimembranosus e gluteus medius. Dietas para fêmeas suínas em fase final de terminação devem conter $15 \mathrm{mg}$ de ractopamina por kg.
\end{abstract}

Palavras-chave: agonista $\beta$ adrenérgico, características de carcaça, desempenho, repartidor de nutrientes

\section{Introduction}

With the purpose of meeting consumer profile changes, which is increasingly demanding pork meat with less fat, the industry and producers have been working to increase the lean proportion in pork carcass. Because of this new situation, a carcass grading system has been implemented by the industry, with an increase in value of carcasses containing a higher percentage of lean tissue (Fávero \& Guidoni, 2001).

The quality of pig carcass is usually directly associated with an increase in the percentage of lean tissue, therefore nutritional advances and the use of metabolism modifiers have contributed to increase carcass quality, thus improving the price paid to producers. Ractopamine is a $\beta$ adrenergic agonist which acts on muscle and fat cells, increasing lean tissue and reducing the fat content of carcasses of finishing pigs. In addition to the positive effects of ractopamine on carcass characteristics (See et al., 2004), it has been previously observed that this additive improves the performance of animals fed diets containing this $\beta$ adrenergic agonist (Crome et al., 1996).

Among the factors that may influence the response of using dietary ractopamine, the most significant variations 
were associated with the concentrations of this agonist, the amount of lysine and other amino acids in the diet, and also with the gender and age of animals at the beginning of its utilization. Dunshea et al. (1993) observed that the addition of up to $20 \mathrm{mg}$ of ractopamine/kg of diet for intact male pigs and also for females and castrated males only produced better results regarding performance and carcass characteristics of castrated males and females, due to the action of male hormones on the growth and potential muscle deposition of intact males. Accordingly, with the increasing use of immunocastration, which benefits from the effect of male sex hormones on carcass characteristics from male pigs, the quality of gilt carcasses is currently the reason for further studies.

With the current tendency to slaughter pigs at a weight up to $110 \mathrm{~kg}$, when the deposition of fat is accentuated and higher than the protein deposition, it is possible that the use of ractopamine may be more pronounced. Thus, the objective of this experiment was to evaluate the effect of ractopamine on performance, carcass characteristics, carcass yield, wholesale cuts, composition and proportion of ham cuts from gilts slaughtered at $110 \mathrm{~kg}$.

\section{Material and Methods}

The experiment was performed in a swine farm located in the city of Taió - Santa Catarina, Brazil. It was used a total of 468 gilts with an initial weight of $84.77 \pm 7.20 \mathrm{~kg}$, distributed in a randomized block design with 4 treatments, 9 replicates and 13 animals per experimental unit. The blocks were formed by using the initial weight of the animals in each pen. The animals were housed in 36 pens $(3.5 \times 4 \mathrm{~m})$ with solid floor, fitted with drinkers and feeders.

The treatments consisted of the inclusion of ractopamine in diets (at 0, 5, 10 and $15 \mathrm{mg} / \mathrm{kg}$ ) in replacement to kaolin (Table 1). The diets were formulated to meet minimal nutritional and energy requirements, as indicated by Rostagno et al. (2005), considering an energy concentration of 3,230 kcal EM/kg of diet, $16.20 \%$ of crude protein and $1.10 \%$ of digestible lysine for gilts with a high potential for lean deposition. A digestible lysine content of $1.10 \%$ was established due to the higher demand of this amino acid when ractopamine is added to diets (Xiao et al., 1999), and the proportions of other amino acids were maintained based on ideal protein concept (Rostagno et al., 2005).

Table 1 - Centesimal, chemical and energy compositions of experimental diets

\begin{tabular}{|c|c|c|c|c|}
\hline \multirow[t]{2}{*}{ Ingredient } & \multicolumn{4}{|c|}{ Ractopamine concentration, mg/kg } \\
\hline & 0 & 5 & 10 & 15 \\
\hline Maize & 77.59 & 77.59 & 77.59 & 77.59 \\
\hline Dicalcium phosphate & 0.81 & 0.81 & 0.81 & 0.81 \\
\hline Calcitic limestone & 0.52 & 0.52 & 0.52 & 0.52 \\
\hline Common table salt & 0.31 & 0.31 & 0.31 & 0.31 \\
\hline L-threonine $(98.5 \%)$ & 0.26 & 0.26 & 0.26 & 0.26 \\
\hline L-tryptophan (98\%) & 0.05 & 0.05 & 0.05 & 0.05 \\
\hline Vitamin supplement ${ }^{1}$ & 0.15 & 0.15 & 0.15 & 0.15 \\
\hline Mineral supplement ${ }^{2}$ & 0.15 & 0.15 & 0.15 & 0.15 \\
\hline Kaolin & 0.89 & 0.64 & 0.49 & 0.12 \\
\hline Ractopamine hydrochloride (2\%) & 0.00 & 0.25 & 0.50 & 0.75 \\
\hline methionine + digestible cystine (\%) & 0.62 & 0.62 & 0.62 & 0.62 \\
\hline digestible threonine (\%) & 0.72 & 0.72 & 0.72 & 0.72 \\
\hline digestible tryptophan (\%) & 0.19 & 0.19 & 0.19 & 0.19 \\
\hline Available phosphorus (\%) & 0.25 & 0.25 & 0.25 & 0.25 \\
\hline Calcium (\%) & 0.48 & 0.48 & 0.48 & 0.48 \\
\hline
\end{tabular}

${ }^{1}$ Vitamin supplement (quantity per kg of product): A vit. - 2,500,000 UI; D3 vit. - 500,000 UI; biotin - 50 mg; choline - 50 mg; niacin - 10,000 mg; calcium pantothenate 3,000 mg; B12 vit. - 7 mg; B2 vit. - 1,800 mg; E vit. - 7,500 mg; K3 vit. - 1,000 mg.

${ }^{2}$ Mineral Supplement (quantity per kg of product): iron - 40,000 mg; copper - 35,000 mg; manganese - 20,000 mg; zinc - 40,000 mg; cobalt - 360 mg; iodine - 840 mg; selenium - $120 \mathrm{mg}$.

${ }^{3}$ Nutritional value of the ingredients, as suggested by Rostagno et al. (2005). 
Rations were offered as three daily meals, and leftovers were collected and weighed at the end of each day. The experimental period was 28 days and, at the end of it, the animals and leftovers from each pen were weighed for performance assessment, which included the evaluation of daily feed intake, daily weight gain and feed conversion. At the end of the experimental period, the animals were slaughtered.

Animals evaluated for carcass characteristics and cut yields were chosen at their last weighing before slaughter. Two animals per pen were selected and only those whose body weight was within the interval corresponding to mean \pm standard deviation of the weight of the animals from the pen were considered. Prior to slaughter on the day following the last weighing, the animals were submitted to a 15-hour fasting without solid food.

After slaughter, the carcasses were sawn lengthwise in halves and then weighed, thus obtaining the hot carcass weight (HCW). Carcass yield was then obtained by associating hot carcass weight with live weight. With the aid of a GP2Q pistol (Hennessy System Ltd., Auckland, New Zealand), fat depth (FD) and loin depth (LD) were measured, thus quantity (QLM) and percentage of lean meat in the carcass (\%LM), were obtained, according to the following equations proposed by Guidoni (2000):

$\mathrm{QLM}=7.38-0.48 \times \mathrm{FD}+0.059 \times \mathrm{LD}+0.525 \times \mathrm{HCW}$ $\% \mathrm{LM}=65.92-0.685 \times \mathrm{FD}+0.094 \times \mathrm{LD}-0.026 \times \mathrm{HCW}$

Then the half-carcasses were taken to the cold chamber at refrigeration temperature $\left(4^{\circ} \mathrm{C}\right)$, for 24 hours, when they were evaluated.

The following measurements were performed on the refrigerated right half-carcass from each animal, according to the Método Brasileiro de Classificação de Carcaças (ABCS, 1973): carcass length, average backfat thickness measured at the first and last thoracic vertebra and also at the last lumbar vertebra, loin eye area, fat area and fat/lean ratio, obtained by dividing the fat area by the loin eye area.

After assessment of carcass characteristics, the right half-carcasses were divided into wholesale cuts of ham, arm shoulder, blade shoulder, loin, belly + ribs and feet, and each cut was weighed. The yield of each cut was calculated, and a relationship was established between its weight and the cooled right carcass weight.

The ham from right half-carcasses was later dissected into meat, bones, skin and fat, which were then weighed. With these weights, the percentage of each component was calculated in relation to the ham weight. Ham meat was further separated into the following retail cuts: quadriceps femoris, semimembranosus, biceps femoris, semitendinosus, gluteus medius and retail, which were also weighed. The yield of each cut was then obtained by dividing its weight by the ham weight. These procedures were carried out at the slaughterhouse.

The data obtained, after being analyzed for error distribution (Cramer Von-Mises test at 5\%, according to Everitt, 1998), were submitted to analysis, using the PROC GLM packet from the SAS software (1998), by performing multiple linear regressions up to the third degree. For the study on animal performance, four diets and nine replicates were used, considering a pen containing 13 animals each as the experimental unit. Four diets and nine replicates were used for assessment of carcass characteristics, weights and yields of carcass wholesale cuts, as well as of ham composition and its retail cuts, and the experimental unit was composed of the mean of two animals from each pen.

\section{Results and Discussion}

No effect $(\mathrm{P}=0.5714)$ was observed on daily weight gain when ractopamine was added to diet (Table 2). A linear effect $(\mathrm{P}<0.05)$ of the treatments was observed on daily intake, which was reduced, according to the equation $\mathrm{Y}=2.478-0.012 \mathrm{X} ; \mathrm{R}^{2}=0.78$. Regarding feed conversion, a linear improvement $(\mathrm{P}<0.05)$ was also observed in relation to the increase of dietary ractopamine, according to the equation $\mathrm{Y}=2.692-0.009 \mathrm{X} ; \mathrm{R}^{2}=0.68$.

Ramos \& Silveira (2001) analyzed the results from studies using pigs fed $\beta$ adrenergic agonists and verified that in most of them, daily weight gain was not significantly affected by the dietary inclusion of such agonists in the diets, a fact confirmed by this experiment. Upon evaluation of the performance of pigs fed diets containing 0,10 and $20 \mathrm{mg}$ of ractopamine/kg, Budiño et al. (2005) observed a

Table 2 - Performance of finishing gilts fed rations containing ractopamine

\begin{tabular}{|c|c|c|c|c|c|c|c|}
\hline \multirow[t]{2}{*}{ Variable } & \multicolumn{4}{|c|}{ Ractopamine concentration (mg/kg) } & \multirow[t]{2}{*}{ CV (\%) } & \multirow[t]{2}{*}{ Regression } & \multirow[t]{2}{*}{$\mathrm{P}$} \\
\hline & 0 & 5 & 10 & 15 & & & \\
\hline Daily feed intake (kg) & 2.45 & 2.38 & 2.39 & 2.27 & 7.80 & Linear & 0.0319 \\
\hline Feed conversion & 2.69 & 2.54 & 2.56 & 2.51 & 5.61 & Linear & 0.0009 \\
\hline
\end{tabular}

${ }^{1} \mathrm{CV}=$ Coefficient of variation. 
higher daily weight gain in animals fed diets containing $20 \mathrm{mg}$ of ractopamine $/ \mathrm{kg}$.

For ration consumption, Ramos \& Silveira (2000) stated that a decreased feed intake promoted by $\beta$ adrenergic agonists would be the result of the stimulation of the central nervous system, whose anabolic effect would continue even in the event of feed restriction. In studies using ruminants, Lafontan et al. (1988) and Gustin et al. (1989) observed reductions in gastric and intestinal motility, slowing down the passage rate and promoting a better utilization of nutrients with a decreased feed intake as consequence.

When evaluating four ways to use ractopamine in diets during 4 weeks (i.e., without ractopamine, at constant ractopamine concentration, at increasing ractopamine concentration and at decreasing ractopamine concentration), See et al. (2004) observed that when there was a decrease in dietary ractopamine, the animals presented a higher feed intake, thus demonstrating the inhibiting effect of ractopamine on ration consumption.

An increase in the retention of nitrogen and consequent increase in the deposition of protein, both promoted by ractopamine, are the main factors responsible for improving the efficiency of nutrient utilization by the animals (See et al., 2004). According to Marinho et al. (2007), this improvement can be explained by a metabolic alteration, represented in this study by an increase in protein synthesis and lipogenesis inhibition, which promotes a higher deposition of muscle and a lower deposition of fat. This suggests that the nutrients have been used in muscle deposition, thanks to the action of this $\beta$ adrenergic agonist.

Crome et al. (1996), when evaluating three ractopamine concentrations ( 0,10 and $20 \mathrm{mg} / \mathrm{kg}$ of diet) for male pigs at $125 \mathrm{~kg}$, observed a reduction in the daily feed intake and a better feed conversion as agonist concentration increased. On the other hand, Armstrong et al. (2004), when evaluating diets for finishing pigs containing $0,5,10$ or $20 \mathrm{mg}$ of ractopamine/kg of diet, verified that animals which received $20 \mathrm{mg} / \mathrm{kg}$ had a better feed efficiency when compared to others, since ration consumption was less pronounced, but without affecting weight gain.

According to the results obtained in this experiment, the best animal performance was observed with the addition of $15 \mathrm{mg}$ of ractopamine/ $\mathrm{kg}$ of diet, a fact evidenced by a better feed conversion. Although Marinho et al. (2007) have found an increase of $3.78 \%$ in the weight at slaughter when they used a concentration of $5 \mathrm{mg}$ of ractopamine $/ \mathrm{kg}$ of diet for finishing pigs in comparison to the treatment without ractopamine, Zagury (2002) observed a better performance when $20 \mathrm{mg} / \mathrm{kg}$ of ractopamine was added, thus demonstrating that the results can be justified when an economic evaluation reveals that it is feasible to use higher or lower concentrations of the additive.

Animals receiving diets containing $15 \mathrm{mg}$ of ractopamine/kg showed better results for carcass characteristics (Table 3), which shows that the agonist affected both lipid metabolism, through a linear reduction observed in fat depth $\left(\mathrm{Y}=13.338-0.038 \mathrm{X} ; \mathrm{R}^{2}=0.92\right)$ and protein metabolism, due to a favorable linear effect verified in the loin eye area $\left(\mathrm{Y}=48.995+0.254 \mathrm{X} ; \mathrm{R}^{2}=0.70\right)$.

When evaluating the addition of 0 and $5 \mathrm{mg}$ of ractopamine $/ \mathrm{kg}$ of diet for pigs slaughtered at $120 \mathrm{~kg}$, Marinho et al. (2007) did not observe any effect on backfat thickness, loin depth and lean percentage, whereas See et al. (2004), using 0 and $10 \mathrm{mg}$ of ractopamine/kg of diet for pigs whose weight at slaughter was next to $110 \mathrm{~kg}$, verified that this $\beta$ adrenergic agonist not only reduced backfat thickness, but it also increased the loin eye area, representing an increase of $6.48 \%$ in the carcass lean. Almeida et al. (2010) also observed that the addition of $5 \mathrm{mg} / \mathrm{kg}$ of ractopamine in diets for pigs increased the loin eye area, consequently improving the fat/lean relationship.

Table 3 - Final weight and carcass characteristics of gilts fed rations containing ractopamine

\begin{tabular}{|c|c|c|c|c|c|c|c|}
\hline \multirow[b]{2}{*}{ Variable } & \multicolumn{4}{|c|}{ Ractopamine concentration, $\mathrm{mg} / \mathrm{kg}$ of diet } & \multirow[t]{2}{*}{ CV (\%) } & \multirow[t]{2}{*}{ Regression } & \multirow[t]{2}{*}{$\mathrm{P}$} \\
\hline & 0 & 5 & 10 & 15 & & & \\
\hline Final weight $(\mathrm{kg})$ & 111.04 & 110.13 & 110.69 & 110.52 & 6.97 & - & 0.3342 \\
\hline Carcass yield $(\%)$ & 71.23 & 72.32 & 72.91 & 72.98 & 4.32 & - & 0.2197 \\
\hline Carcass length $(\mathrm{cm})$ & 99.00 & 101.38 & 99.25 & 103.00 & 3.61 & - & 0.2230 \\
\hline Average backfat thickness $(\mathrm{cm})$ & 2.22 & 2.15 & 2.13 & 2.12 & 7.46 & - & 0.2132 \\
\hline Quantity of lean meat (kg) & 48.92 & 49.81 & 49.77 & 49.78 & 3.63 & - & 0.2006 \\
\hline Percentage of lean meat (\%) & 60.47 & 61.30 & 61.41 & 61.56 & 8.94 & linear & 0.0339 \\
\hline Loin eye area $\left(\mathrm{cm}^{2}\right)$ & 48.17 & 51.25 & 51.14 & 52.31 & 7.21 & linear & 0.0414 \\
\hline Fat area $\left(\mathrm{cm}^{2}\right)$ & 13.49 & 13.38 & 13.09 & 12.87 & 5.80 & - & 0.1148 \\
\hline Fat/lean relation & 0.28 & 0.26 & 0.26 & 0.25 & 9.11 & linear & 0.0120 \\
\hline
\end{tabular}

$\mathrm{CV}=$ Coefficient of variation. 
According to Bridi et al. (2008), in order to evidence the effects of ractopamine on carcass characteristics and protein synthesis in muscle tissue, it is necessary to supply a content of proteins and amino acids (particularly lysine) which are above the values conventionally used in diets for finishing pigs. Armstrong et al. (2004) have recommended that the contents of crude protein and lysine in diets containing ractopamine must be greater than 16 and $1 \%$, respectively, with a further proportional inclusion of other amino acids in relation to dietary lysine contents.

Increasing dietary ractopamine concentrations have promoted linear increases $(\mathrm{P}<0.05)$ in ham weight, as well as in arm shoulder weight and yield in gilts (Table 4 ).

These results are similar to the ones obtained by Uttaro et al. (1993) who, when evaluating the inclusion of $20 \mathrm{mg}$ of ractopamine/ $\mathrm{kg}$ of diet, observed an increase on arm shoulder weight but not on ham. Similarly, these results are also in consonance with the ones obtained by Crome et al. (1996), who tested increasing ractopamine concentrations ( 0,10 and $20 \mathrm{mg} / \mathrm{kg}$ of diet). They observed favorable effects on the weight of wholesale cuts of ham, loin, arm shoulder and blade shoulder. However, the results obtained are different from those observed by Cantarelli et al. (2008), who studied the inclusion of $5 \mathrm{mg}$ of ractopamine/kg of diet and did not find effects on the ham, arm shoulder, blade shoulder and loin weight, but found a higher percentage of meat in all cuts.

The addition of increasing ractopamine concentrations in diets for gilts linearly reduced the amount of fat $(\mathrm{Y}=1.479$ $\left.0.012 \mathrm{X} ; \mathrm{R}^{2}=0.66\right)$ and increased the lean content of ham $\left(\mathrm{Y}=8.129+0.057 \mathrm{X} ; \mathrm{R}^{2}=0.89\right)$, thus evidencing that ractopamine acted on protein metabolism through a linear increase in meat, as well as on lipid metabolism, as it reduced the amount of ham fat (Table 5).

Similar results were obtained by Bellaver et al. (1991), who evaluated three ractopamine levels ( 0,10 and $20 \mathrm{mg} / \mathrm{kg}$ of diet) and observed that the utilization of this agonist reduced fat weight and increased the lean weight of ham from pigs slaughtered at $100 \mathrm{~kg}$. Although Crome et al. (1996) did not observe any effect of the addition of increasing ractopamine concentrations on the quantity of skin and bones in ham, the same authors observed reductions in subcutaneous and intermuscular fat, in addition to an increase in the lean quantity of this cut.

Table 4 - Mean weights (kg) and yields (\%) of wholesale cuts of right half-carcasses of gilts fed different dietary ractopamine concentrations

\begin{tabular}{|c|c|c|c|c|c|c|c|}
\hline \multirow[t]{2}{*}{ Wholesale Cut } & \multicolumn{4}{|c|}{ Ractopamine concentration, mg/kg } & \multirow[t]{2}{*}{ CV ( \%) } & \multirow[t]{2}{*}{ Regression } & \multirow[t]{2}{*}{$\mathrm{P}$} \\
\hline & 0 & 5 & 10 & 15 & & & \\
\hline Ham (kg) & 12.31 & 12.37 & 12.87 & 13.02 & 5.37 & Linear & 0.0210 \\
\hline Blade shoulder (kg) & 3.95 & 3.71 & 4.10 & 4.17 & 8.69 & - & 0.0702 \\
\hline Loin $(\mathrm{kg})$ & 6.05 & 5.89 & 6.01 & 5.93 & 9.81 & - & 0.7767 \\
\hline Belly and ribs (kg) & 6.24 & 6.48 & 6.18 & 6.26 & 8.29 & - & 0.7856 \\
\hline Arm shoulder (\%) & 22.64 & 22.67 & 22.87 & 23.34 & 3.44 & Linear & 0.0135 \\
\hline Blade shoulder (\%) & 10.41 & 9.38 & 10.59 & 10.59 & 10.36 & - & 0.3070 \\
\hline Loin $(\%)$ & 15.92 & 14.87 & 15.45 & 15.50 & 8.08 & - & 0.2699 \\
\hline Belly and ribs (\%) & 16.43 & 16.56 & 15.90 & 15.98 & 7.48 & - & 0.2781 \\
\hline Feet (\%) & 1.03 & 0.94 & 0.99 & 0.98 & 10.35 & - & 0.2227 \\
\hline
\end{tabular}

$\overline{\mathrm{CV}}=$ Coefficient of variation.

Table 5 - Mean weights (kg) and yields (\%) of bones, skin, fat and lean of ham from gilts fed diets containing different ractopamine concentrations

\begin{tabular}{|c|c|c|c|c|c|c|c|}
\hline \multirow[t]{2}{*}{ Ham composition } & \multicolumn{4}{|c|}{ Ractopamine concentration (mg/kg) } & \multirow[t]{2}{*}{ CV (\%) } & \multirow[t]{2}{*}{ Regression } & \multirow[t]{2}{*}{$\mathrm{P}$} \\
\hline & 0 & 5 & 10 & 15 & & & \\
\hline Bones (kg) & 1.43 & 1.44 & 1.39 & 1.44 & 8.38 & - & 0.9687 \\
\hline Skin $(\mathrm{kg})$ & 0.82 & 0.84 & 0.82 & 0.82 & 6.65 & - & 0.8753 \\
\hline Fat (kg) & 1.49 & 1.43 & 1.34 & 1.34 & 11.22 & linear & 0.0307 \\
\hline Lean (kg) & 8.05 & 8.51 & 8.74 & 8.94 & 5.74 & linear & 0.0035 \\
\hline Bones (\%) & 11.65 & 11.62 & 10.80 & 11.16 & 10.28 & - & 0.2152 \\
\hline Skin (\%) & 6.69 & 6.75 & 6.36 & 6.35 & 7.69 & - & 0.0804 \\
\hline Fat $(\%)$ & 12.20 & 11.56 & 10.46 & 10.33 & 11.60 & linear & 0.0026 \\
\hline Lean (\%) & 65.41 & 67.32 & 67.92 & 68.87 & 7.87 & linear & 0.0004 \\
\hline
\end{tabular}

$\mathrm{CV}=$ Coefficient of variation. 
According to Armstrong et al. (2004), the prediction of lean meat in carcasses using equations may underestimate the magnitude of the effects of ractopamine, since such effects are limited to sites where the measurements considered in the equations are carried out. Schinckel et al. (2003) stated that the most accurate prediction of lean composition of carcasses of pigs fed diets containing ractopamine is obtained when more precise measures are used, such as ham dissection or chemical analyzes. In this study, increasing ractopamine levels in diets caused a favorable linear effect, both in lean percentage (Table 3), which has been obtained by equations, and in the lean yield of ham (Table 5), obtained by dissection.

It has been observed a favorable linear effect (Table 6) of the addition of ractopamine on the semimembranosus ( $\left.\mathrm{Y}=1.983+0.014 \mathrm{X} ; \mathrm{R}^{2}=0.67\right)$ and gluteus medius $\left(\mathrm{Y}=1.349+0.014 \mathrm{X} ; \mathrm{R}^{2}=0.88\right)$ weights and on the semimembranosus yield $\left(\mathrm{Y}=16.004+0.070 \mathrm{X} ; \mathrm{R}^{2}=0.58\right)$. According to Mills (2002), the addition of ractopamine in diets promotes an increase in protein synthesis and a decrease in the degradation of muscle protein, which is evidenced by higher levels of messenger RNA of myosin and actin. Furthermore, the same author stated that it was observed an increase in the blood circulation of skeletal muscles in animals which consumed diets containing ractopamine, with an alteration in muscle fibers favoring the fast twitch ones. Therefore, due to the prevalence of fast twitch muscle fibers in the gluteus medius and semimembranosus muscles (Karlsson et al., 1999), this study verified that the addition of increasing ractopamine concentrations in diets promoted linear increases in the weight of the same muscles.

According to Dunshea et al. (1993), the effect of inclusion of $20 \mathrm{mg}$ of ractopamine/kg of diet for pigs on the diameter of muscle fibers promoted an increase of $6.4 \%$ on the diameter of fast twitch muscle fibers, which corresponds to the same increase observed in the meat yield of carcasses.

When evaluating the addition of $20 \mathrm{mg}$ of ractopamine $/ \mathrm{kg}$ of diet for castrated male pigs and gilts, Xiao et al. (1999) also observed significant increases in the weights of the semimembranosus, biceps femoris and semitendinosus muscles, and only numerical increases were found in the weight of the quadriceps femoris and gluteus medius muscles. According to these authors, different responses by the muscles studied can be associated with a higher participation of fast twitch muscle fibers and with the quantity of adrenergic receptors in the muscles.

Table 6 - Mean weights $(\mathrm{kg})$ and yields (\%) of retail cuts of ham from gilts fed diets containing ractopamine

\begin{tabular}{|c|c|c|c|c|c|c|c|}
\hline \multirow[t]{2}{*}{ Retail cut } & \multicolumn{4}{|c|}{ Ractopamine concentration (mg/kg) } & \multirow[t]{2}{*}{ CV (\%) } & \multirow[t]{2}{*}{ Regression } & \multirow[t]{2}{*}{$\mathrm{P}$} \\
\hline & 0 & 5 & 10 & 15 & & & \\
\hline Retail (kg) & 0.99 & 1.08 & 1.06 & 1.09 & 9.64 & - & 0.0954 \\
\hline Quadriceps femoris (kg) & 1.50 & 1.68 & 1.64 & 1.66 & 12.07 & - & 0.1702 \\
\hline Semimembranosus (kg) & 1.93 & 2.14 & 2.18 & 2.17 & 7.40 & Linear & 0.0050 \\
\hline Biceps femoris (kg) & 1.81 & 1.88 & 1.90 & 1.89 & 10.47 & - & 0.3945 \\
\hline Semitendinosus (kg) & 0.49 & 0.54 & 0.54 & 0.56 & 14.33 & - & 0.0783 \\
\hline Gluteus medius (kg) & 1.33 & 1.42 & 1.42 & 1.57 & 9.04 & Linear & 0.0022 \\
\hline Retail (\%) & 8.07 & 8.80 & 8.26 & 8.38 & 10.86 & - & 0.7640 \\
\hline Quadriceps femoris (\%) & 12.19 & 13.64 & 12.75 & 12.75 & 11.20 & - & 0.7264 \\
\hline Semimembranosus (\%) & 15.70 & 16.83 & 16.92 & 16.92 & 7.94 & Linear & 0.0412 \\
\hline Biceps femoris (\%) & 14.65 & 15.22 & 14.79 & 15.57 & 10.07 & - & 0.7695 \\
\hline Semitendinosus (\%) & 3.96 & 4.37 & 4.21 & 4.32 & 14.65 & - & 0.3505 \\
\hline Gluteus medius (\%) & 10.85 & 10.96 & 10.98 & 12.11 & 9.56 & - & 0.0553 \\
\hline
\end{tabular}

${ }^{1} \mathrm{CV}=$ Coefficient of variation.

\section{Conclusions}

The addition of $15 \mathrm{mg}$ of ractopamine/kg of diet promotes a better feed conversion and increases the lean percentage of carcasses of finishing gilts.

\section{References}

ALMEIDA,V.V.; BERENCHTEIN, B.; COSTA, L.B. et al. Ractopamina, cromo-metionina e suas combinações como aditivos modificadores do metabolismo de suínos em crescimento e terminação. Revista Brasileira de Zootecnia, v.39, n.9, p.1969-1977, 2010.

ASSOCIAÇÃO BRASILEIRA DE CRIADORES DE SUÍNOS - ABCS Método brasileiro de classificação de carcaças. Estrela: ABCS, 1973. 17p. (Publicação Técnica, 2).

ARMSTRONG, T.A.; IVERS, D.J.; WAGNER, J.R. et al. The effect of dietary ractopamine concentration and duration of feeding on growth perfomance, carcass characteristics, and meat quality of finishing pigs. Journal of Animal Science, v.82, n.11, p.3245-3253, 2004.

BELlAVER, C.; FIALHO, E.T.; FÁVERO, J.A. et al. Níveis de ractopamina na dieta e efeitos sobre o desempenho e características de carcaça de suínos em terminação. Pesquisa Agropecuária Brasileira, v.26, n.10, p.1795-1802, 1991. 
BRIDI, A.M.; OLIVEIRA, A.R.; FONSECA, N.A. et al. Efeito da ractopamina e do gênero no desempenho e na carcaça de suínos de diferentes genótipos halotano. Semina: Ciências Agrárias, v.29, n.3, p.713-722, 2008.

BUDIÑO, F.E.L.; THOMAZ, M.C.; NEME, R. et al. Desempenho e características de carcaça de suínos em terminação recebendo diferentes níveis e marcas comerciais de cloridrato de ractopamina. Boletim da Indústria Animal, v.62, n.3, p.245-250, 2005.

CANTARELLI, V.S.; ZANGERONIMO, M.G.; ALMEIDA, E.C. et al. Qualidade de cortes de suínos recebendo ractopamina na ração em diferentes programas alimentares. Acta Scientiarum Animal Sciences, v.30, n.2, p.165-171, 2008.

CROME, P.K.; McKEITH, F.K.; CARR, T.R. et al. Effect of ractopamine on growth performance, carcass composition and cutting yields of pigs slaughtered at 107 and 125 kilograms. Journal of Animal Science, v.74, n.4, p.709-716, 1996.

DUNSHEA, F.R.; KING, R.H.; CAMPBELL, R.G. et al. Interrelationships between sex and ractopamine on protein and lipid deposition in rapidly growing pigs. Journal of Animal Science, v.71, n.11, p.2919-2930, 1993.

EVERITT, B.S. The Cambridge dictionary of statistics. Cambridge: Cambridge University Press, 1998. 360p.

FÁVERO, J.A.; GUIDONI, A.L. Normatização e padronização da tipificação de carcaças de suínos no Brasil - aspectos positivos e restrições. In: CONFERÊNCIA INTERNACIONAL VIRTUAL SOBRE QUALIDADE DE CARNE SUÍNA, 2., 2001, Concórdia. Anais... Concórdia: EMBRAPA-CNPSA, 2001. p.73-79.

GUIDONI, A.L. Melhoria dos processos para tipificação de carcaças suínas no Brasil. In: CONFERÊNCIA INTERNACIONAL VIRTUAL SOBRE QUALIDADE DE CARNE SUÍNA, 1., 2000, Concórdia. Anais eletrônicos... Disponível em: <http:// www.cnpsa.embrapa.br/pork>. Acesso em: 12/2/2006.

GUSTIN, P.; ANSAY, M.; MAGHUIN-ROGISTER, G. La pharmacologie et le problème des résidus des agonistes $\beta 2$ adrenérgiques chez les bovins. Annales de Médecine Vétérinaire, v.133, p.293-311, 1989.

KARLSSON, A.H.; KLONT, R.E.; FERNANDEZ, X. Skeletal muscle fibres as factors for pork quality. Livestock Production Science, v.60, p.255-269, 1999.

LAFONTAN, M.; BERLAN, M.; PRUD`HON, M. Les agonistes beta-adrénergiques. Mecanismes d'action: lipomobilisation et anabolisme. Reproduction Nutrition Development, v.28, p.61-84, 1988 .

MARINHO, P.C.; FONTES, D.O.; SILVA, F.C.O. et al. Efeito da ractopamina e de métodos de formulação de dietas sobre o desempenho e as características de carcaça de suínos machos castrados em terminação. Revista Brasileira de Zootecnia, v.36, n.4, p.1061-1068, 2007.

MILLS, S.E. Biological basis of the ractopamine response. Journal of Animal Science, v.80, p.E28-E32, 2002. (E. Suppl. 2)

RAMOS, F.; SILVEIRA, M.I.N. Agonistas adrenérgicos $\beta 2$ e produção animal. I - Mecanismo de acção. Revista Portuguesa de Ciências Veterinárias, v.95, p.99-110, 2000.

RAMOS, F.; SILVEIRA, M.I.N. Agonistas adrenérgicos $\beta 2$ e produção animal: II - relação estrutura-actividade e farmacocinética. Revista Portuguesa de Ciências Veterinárias, v.96, p.167175, 2001.

ROSTAGNO, H.S.; ALBINO, L.F.T.; DONZELE, J.L. et al. Tabelas brasileiras para aves e suínos - Composição de alimentos e exigências nutricionais. Viçosa, MG: Imprensa Universitária/ UFV, 2005. 141p.

SAS INSTITUTE. SAS user's guide: statisic - Cary: SAS Institute, 1998. 211p.

SCHINCKEL, A.P.; LI, N.; RICHERT, B.T. et al. Development of a model to describe the compositional growth and dietary lysine requirements of pigs fed ractopamine. Journal of Animal Science, v.81, n.5, p.1106-1119, 2003.

SEE, M.T.; ARMSTRONG, T.A.; WELDON, W.C. Effect of a ractopamine feeding program on growth performance and carcass composition in finishing pigs. Journal of Animal Science, v.82, n.8, p.2474-2480, 2004

UTTARO, R.E.; BALL, R.O.; DICK, P. et al. Effect of ractopamine and sex on growth, carcass characteristics, processing yield, and meat quality characteristics of crossbred swine. Journal of Animal Science, v.71, n.9, p.2439-2449, 1993.

XIAO, R.J.; XU, Z.R.; CHEN, H.L. Effects of ractopamine at different dietary protein levels on growth performance and carcass characteristics in finishing pigs. Animal Feed Science and Technology, v.79, n.1, p.119-127, 1999.

ZAGURY, F.T.R. Abate de suínos pesados: vale a pena? Porkworld, v.1, n.4, p.30-34, 2002. 